\title{
ORCHID GROWTH AND NUTRITION IN RESPONSE TO MINERAL AND ORGANIC FERTILIZERS ${ }^{(1)}$
}

\author{
Donizetti Tomaz Rodrigues ${ }^{(2)}$, Roberto Ferreira Novais ${ }^{(3)}$, Víctor \\ Hugo Alvarez V. ${ }^{(3)}$, José Maria Moreira Dias ${ }^{(4)}$ \& Ecila Mercês de \\ Albuquerque Villani ${ }^{(5)}$
}

\begin{abstract}
SUMMARY
Orchid fertilization is fundamental for a satisfactory plant growth and development for commercial orchid production as well as in collections. Mineral and/or organic sources can be used for fertilization. The objective of this study was to evaluate the effect of the use of organic and/or mineral fertilizers on the nutrition and growth of orchid (Laelia purpurata 'werkhanserii' x L. lobata 'Jeni') seedlings in greenhouse. The following fertilizers were tested: an NPK fertilizer + micronutrients; a Ca source in the form of calcium nitrate; two organic fertilizers, one prepared with a mixture of bone meal, castor meal and ash, and a similar commercial fertilizer. The organic fertilizers were distributed on the surface of the pots every two months and the minerals were applied weekly to the substrate in $25 \mathrm{~mL}$ aliquots of a solution containing $1 \mathrm{~g} \mathrm{~L}^{-1}$ of the respective fertilizer. The plant response to the application of mineral together with organic fertilizer was better, with higher dry matter production than by the isolated application of each fertilizer (organic or mineral). The treatments with calcium nitrate + NPK fertilizer did not differ significantly from the use of NPK fertilizer, probably due to the $\mathrm{S}$ deficiency detected in a mineral analysis of the tissues. Commercial organic fertilizer had a very elevated B level, leading to toxicity symptoms, reduced growth and necrotized tips of the older leaves in all fertilized treatments.
\end{abstract}

Index terms: orchidaceae, fertilizer, B toxicity, bone meal, castor meal, ash.

\footnotetext{
(1) Received for publication in March 2009 and approved in July 2010.

(2) Graduate student in Soils and Plant nutrition, Federal University of Viçosa, Soil Department, Av. PH Rolfs s/n, 36570-000 Viçosa (MG). E-mail: donitom@yahoo.com.br

(3) Full professor, Federal University of Viçosa, Soil Department, Av. PH Rolfs s/n, CEP 36570-000 Viçosa (MG). E-mails: rfnovais@ufv.br; vhva@ufv.br

(4) Full professor, Federal University of Viçosa, Plant Science Department, Av. PH Rolfs s/n, CEP 36570-000 Viçosa (MG). E-mail: jmmdias@ufv.br

(5) PhD, Federal University of Viçosa, Soil Department. E-mail: ecilavillani@yahoo.com.br
} 


\title{
RESUMO: CRESCIMENTO E NUTRIÇÃO DE ORQUÍDEA EM RESPOSTA À FERTILIZAÇÃO MINERAL E ORGÂNICA
}

\begin{abstract}
A fertilização de orquídeas é fundamental para crescimento e desenvolvimento satisfatórios tanto em orquidários comerciais quanto em coleções. Essa fertilização pode ser realizada com fontes minerais e, ou, orgânicas. Este trabalho teve como objetivo avaliar o efeito do uso de fertilizantes orgânicos e, ou, minerais sobre a nutrição e crescimento de mudas de orquídeas (Laelia purpurata 'werkhanserii' $x$ L. lobata 'Jeni') em casa de vegetação. Foram utilizados: um fertilizante mineral NPK + micronutrientes; uma fonte de Ca na forma de nitrato de cálcio; e dois fertilizantes orgânicos, um preparado com a mistura de farinha de ossos, torta de mamona e cinzas e outro semelhante a esse último adquirido no comércio (comercial). Os fertilizantes orgânicos foram distribuidos sobre a superfície dos vasos a cada dois meses, e os minerais foram aplicados semanalmente no substrato em aliquotas de $25 \mathrm{~mL}$ de uma solução contendo $1 \mathrm{~g} \mathrm{~L}^{-1}$ do respectivo fertilizante. Os resultados demonstraram melhores respostas para uso do fertilizante mineral juntamente com o fertilizante orgânico, apresentando maior produção de matéria seca das plantas em relação ao uso isolado de cada fertilizante (orgânico ou mineral). Os tratamentos que receberam nitrato de cálcio adicionalmente ao fertilizante NPK não apresentaram diferenças significativas em comparação ao uso do fertilizante NPK, provavelmente por deficiência de $S$, evidenciada na análise mineral dos tecidos. O fertilizante orgânico comercial mostrou teor muito elevado de $B$, refletindo em sintomas de toxidez, crescimento reduzido e extremidades de folhas mais velhas necrosadas, em todos os tratamentos que receberam esse fertilizante.
\end{abstract}

Termos de indexação: orchidaceae, fertilizantes, toxidez de B, farinha de ossos, torta de mamona, cinzas.

\section{INTRODUCTION}

Traditionally, orchids were not fertilized since it was believed that nutrients in the cultivation substrate were sufficient to maintain plant growth and development. Well-fertilized plants, however, have noticeably better flowers, an earlier adult phase, and an important increase in pest and disease resistance. However, as the level of technology applied increases, the risk of plant losses increase as well. This shows that there are limits for nutrient applications, with excellent results at adequate rates and the possibility of death due to nutrient toxicity and/or salinity when nutrients are supplied in excess (Novais \& Rodrigues, 2004).

There are various fertilizer mixtures that can be used for orchids. Research results show that concentrations between 1 and $2 \mathrm{~g} \mathrm{~L}^{-1}$ of water-soluble fertilizer, applied weekly by fertilization, are satisfactory for plant growth and development (Wang \& Gregg, 1994; Wang, 1996; Amberger-Ochsenbauer, 1997; Wang, 2000).

Wang (1996) found no statistical differences between six water-soluble NPK mixtures (10-30-20, 15-20-30, 15-20-25, 20-5-19, 20-10-20, and 20-20-20) which he tested at concentrations of 100 or $200 \mathrm{mg} \mathrm{L}^{-1}$, applied to Phaleanopsis by fertilization/irrigation. This author concluded that the highest concentration (200 mg L-1, corresponding to $1.0 \mathrm{~g} \mathrm{~L}^{-1}$ of $20-20-20$ ) should be used in the initial growth phase. For adult plants however, a lower concentration should be used to avoid exaggerated leaf growth, which would require more space on the benches, thus raising production costs.

Orchids have good nutrient cycling, principally in those plants that have reserve structures, such as pseudobulbs. Erickson (1957), studying the nutritional composition of leaves of one to seven-yearold Cattleya grown in osmunda fiber, verified that the N, P and K concentrations decreased, Ca increased and $\mathrm{Mg}$ remained stable with increasing leaf age. This result was probably a consequence of retranslocation of the three nutrients from the older leaves to younger growing tissue.

Novais ${ }^{(6)}$ reported good initial results with fertilizer application at concentrations in the order of $13 \mathrm{~g} \mathrm{~L}^{-1}$ in irrigation water, with a higher number of shoots and larger leaves. However, a few months later he observed that in most species the roots began to die, probably due to salt accumulation in the velamen. On the other hand, Rodrigues et al. (2002) obtained excellent results with a hybrid of Cattleya harrisoniae and $C$. loddigessi using a $13 \mathrm{~g} \mathrm{~L}^{-1}$ salt solution. It is worth mentioning that different doses of the solution were used in these experiments, and that root tip death frequently occurred at higher rates $\left(100 \mathrm{~mL} \mathrm{dm}^{-3}\right)$, without altering the dry matter production of the plants, which flowered normally.

Another relevant fact related to water-soluble fertilizers utilized in orchid cultivation, e.g., Peters ${ }^{\circledR}$,

\footnotetext{
(6) Roberto Ferreira Novais, Professor, UFV Soil Department - Personal Information.
} 
is the deficiency of some nutrients, for example of $\mathrm{Ca}$ and $\mathrm{S}$. A lack of $\mathrm{Ca}$ in orchids provokes death in some growth regions, as of the stem and root apexes, as well as making the plant more susceptible to pests and disease (Rodrigues, 2005).

Specific organic fertilizers for orchids are available on the market, some of which greatly stimulate rooting and vegetative growth. Generally, they consist of bone or shell meal, castor meal and contain additional substances such as IBA (Indolebutyric Acid) that stimulate rooting in some cases (Novais \& Rodrigues, 2004).

Most studies on fertilization of orchids deal with the genera Cattleya, Epidendrum, Dendrobium and in particular, Phalaenopsis, in view of the great market demand, whereas, for the genus Laelia, such information is rare. In this experiment, the response to organic and/or mineral fertilizer of hybrid plants of Laelia purpurata 'werkhanserii' x L. lobata 'Jeni' was evaluated.

\section{MATERIALS AND METHODS}

The experimental unit consisted of a $0.5 \mathrm{~L}$ pot with a gravel layer (gnaiss grain size 2.3 - $12.7 \mathrm{~mm}$ ) corresponding to $100 \mathrm{~cm}^{3}$ covered with $400 \mathrm{~cm}^{3}$ of treefern fiber (xaxim), with one seed-grown plantlet (Laelia purpurata 'werkhanserii' x L. lobata 'Jeni'), approximately 18 months old. The pots were placed on benches protected by $50 \%$ shade screen, between August 2003 and May 2004 (10 months), in a greenhouse of the Soil Department of the Federal University of Viçosa, Minas Gerais State, Brazil.

The fertilization treatments evaluated in the experiment consisted of a factorial combination of the presence of fixed quantities or absence of two organic manures with and without the application of a fixed quantity of four mineral fertilizers (Table 1). The manures were a commercial organic fertilizer and a "domestic" organic fertilizer consisting of a mixture of castor meal, bone meal and ash in the proportion $2: 1: 1 \mathrm{v} / \mathrm{v} / \mathrm{v}$, respectively. The ash used was obtained in a wood oven. The mineral fertilizers were calcium nitrate (NCa), Peters 20-20-20+ micronutrients (PTr) and half of NCa + PTr. Organic fertilizers were applied over the pot surface every two months and the mineral fertilizers were applied via aqueous solutions containing $1 \mathrm{~g} \mathrm{~L}^{-1}$ of fertilizer; the combinations or organic and mineral fertilizers were applied considering the intervals for each source of fertilizer. The treatments were arranged in randomized blocks with five replications. The total and soluble contents of macro and micronutrients in the organic fertilizers were determined according to Embrapa (1999).

The experiment was irrigated to maintain an adequate moisture level of the substrate for the plants under study. After ten months, the following traits were evaluated: shoot length and number of shoot units (SU), root dry matter, shoot dry matter, root/ shoot ratio and nutrient level in the aerial plant tissue.

The plant shoot samples were dried in a forced-air oven at $70{ }^{\circ} \mathrm{C}$, ground and digested (nitric-perchloric acid) for nutrient determination. Levels of $\mathrm{P}, \mathrm{K}, \mathrm{Ca}$, $\mathrm{Mg}, \mathrm{S}, \mathrm{Fe}, \mathrm{Zn}, \mathrm{Mn}, \mathrm{B}$ and $\mathrm{Cu}$ were determined by inductively coupled plasma optical emission spectrometry, and $\mathrm{N}$ by the semi-micro-Kjedahl method (Embrapa, 1999).

The statistical analyses of all response variables were carried out using the SAEG 9.0 program, and the means of each organic manure combination with and without mineral fertilizers and the means of each manure source/rate were compared, according to the Tukey test a $5 \%$.

Table 1. Organic and mineral fertilizers in the tested combinations and quantities

\begin{tabular}{|c|c|c|c|c|c|}
\hline \multirow{3}{*}{ Treatment } & \multirow{3}{*}{ Key ident. } & \multicolumn{4}{|c|}{ Rate } \\
\hline & & \multicolumn{2}{|c|}{ For application } & \multicolumn{2}{|c|}{ Total } \\
\hline & & Organic & Mineral & Organic & Mineral \\
\hline & & g/pot & $\mathrm{mL} / \mathrm{pot}$ & $\longrightarrow$ & $/$ pot \\
\hline Control & None & 0 & 0 & 0 & 0,000 \\
\hline Calcium nitrate & $\mathrm{CaN}$ & 0 & 25 & 0 & 1,075 \\
\hline Peters $^{\circledR}$ & $\mathrm{PTr}$ & 0 & 25 & 0 & 1,075 \\
\hline Calcium nitrate + Peters ${ }^{\circledR}$ & $\mathrm{CaN}+\mathrm{PTr}$ & 0 & 25 & 0 & $0,5375+0,5375$ \\
\hline Commercial Organic & $\mathrm{CO}$ & 8 & 0 & 40 & 0,000 \\
\hline Commercial Organic + Calcium nitrate & $\mathrm{CO}$ and $\mathrm{CaN}$ & 8 & 25 & 40 & 1,075 \\
\hline Commercial Organic + Peters ${ }^{\circledR}$ & $\mathrm{CO}$ and $\mathrm{PTr}$ & 8 & 25 & 40 & 1,075 \\
\hline Commercial Organic + Calcium nitrate + Peters ${ }^{\circledR}$ & $\mathrm{CO}$ and $\mathrm{CaN}+\mathrm{PTr}$ & 8 & 25 & 40 & $0,5375+0,5375$ \\
\hline Domestic Organic & DO & 8 & 0 & 40 & 0,000 \\
\hline Domestic Organic + Calcium nitrate & $\mathrm{DO}$ and $\mathrm{CaN}$ & 8 & 25 & 40 & 1,075 \\
\hline Domestic Organic + Peters ${ }^{\circledR}$ & DO and PTr & 8 & 25 & 40 & 1,075 \\
\hline Domestic Organic + Calcium nitrate + Peters & $\mathrm{DO}$ and $\mathrm{CaN}+\mathrm{PTr}$ & 8 & 25 & 40 & $0,5375+0,5375$ \\
\hline
\end{tabular}




\section{RESULTS AND DISCUSSION}

In this study, excess shoots, deformed leaves and a darker green color were observed on plants treated with commercial organic fertilizer (CO) than in absence thereof. These characteristics led to the hypothesis of B toxicity, keeping in mind that this fertilizer source contained a very high B level (Table 2 ), resulting in very high B plant levels (Table 4). The principal symptom of $\mathrm{B}$ toxicity is chlorosis on the edges and/or apexes of old leaves, followed by necrosis (Nable et al., 1997). In the plant shoot (leaves + pseudobulb). Boron levels between 271 and $388 \mathrm{mg} \mathrm{kg}^{-1}$ were found, which is extremely high, compared to the levels considered adequate (Table 4). Carlucci et al. (1989) suggested that adequate levels lie in the range of 35 to $63 \mathrm{mg} \mathrm{kg}^{-1}$, Jones Jr. et al. (1991) between 25 and 75, and Arditti (1992) between 25 and $50 \mathrm{mg} \mathrm{kg}^{-1}$.

The B levels of plants in treatments without CO application varied from 36 to $74 \mathrm{mg} \mathrm{kg}^{-1}$, and no visual toxicity symptoms were observed (Table 4).

Domestic organic fertilizer (DO), due to its origin, may have a more equilibrated composition with more balanced nutrient levels, while Peters ${ }^{\circledR}$ fertilizer had some limitations, such as lack of $\mathrm{Ca}, \mathrm{S}$ and low micronutrient levels in the majority of the mixtures (Novais \& Rodrigues, 2004). Application of Peters $\mathbb{R}$ with DO resulted in an increase in shoot dry matter in the order of $40 \%$ compared to the separate application of these fertilizers (Table 3). This increase in dry matter production appears to be a result of increased supply of $\mathrm{N}, \mathrm{P}, \mathrm{K}$ and $\mathrm{Ca}$, since orchids, especially younger plants, are highly responsive to these nutrients (Rodrigues, 2005). In this case, DO fertilizer complemented the deficiency of Peters ${ }^{\circledR}$ in $\mathrm{Ca}, \mathrm{S}$ and micronutrients and provided the other nutrients more continuously and in a way that maintained electrical conductivity low in the substrate solution.

In addition to the toxic $\mathrm{B}$ effect in the shoot, lower dry matter in the root system occurred in CO-treated plants (Table 3). The growth of the root system, in this case, was limited and had abnormal darkened coloration and most roots were dead. A fact that may also have caused root death was poor aeration of the substrate since the organic fertilizers were distributed uniformly across the entire surface; after several applications, a crust was formed that restricted evaporation, causing a hypoxia-favorable environment. This problem also occurred in the DO treatment, although in this case the crust formed on the surface was more permeable and the problem was not as severe as in the previous case. It can thus be proposed that organic fertilizers on orchids should be applied in a localized form, along the edges of the pot, in order to avoid crust formation.

As a result of low root dry matter (Table 3) in COtreated plants, the average values of the root/shoot ratio (R/S) were around 0.25 ; on the other hand, plants that received only mineral fertilizer had $\mathrm{R} / \mathrm{S}$ values of around 0.73 ; for DO, the values were around 0.41; the $\mathrm{R} / \mathrm{S}$ ratio of unfertilized plants was equal to 0.99 (Table 3).

In terrestrial plants, root production is strongly influenced by soil-related factors such as the availability of nutrients and their physical, chemical and microbial characteristics. Among these factors, it is known that R/S increases as soil fertility decreases (Marschner, 1995; Meurer, 2007) as an indicator of stress conditions. Under such conditions, the roots are provided with a proportionally greater quantity of photoassimilates as defense strategy, to compensate for the scarce nutrition in the substrate with a larger root volume. Therefore, the R/S in orchids with good

Table 2. Concentrations of macro- and micronutrients in Peters ${ }^{\circledR}$ 20-20-20 combined with commercial organic (CO) and domestic organic fertilizers (DO)

\begin{tabular}{|c|c|c|c|c|c|}
\hline \multirow{2}{*}{ Nutrient } & \multirow{2}{*}{ Peters $^{(1)}$} & \multicolumn{2}{|c|}{$\mathrm{CO}$} & \multicolumn{2}{|c|}{ DO } \\
\hline & & Total & Soluble in $\mathrm{H}_{2} \mathrm{O}$ & Total & Soluble in $\mathrm{H}_{2} \mathrm{O}$ \\
\hline & \multicolumn{5}{|c|}{$\mathrm{g} \mathrm{kg}^{-1}$} \\
\hline $\mathrm{N}$ & 200.0 & 62.9 & - (2) & 21.5 & -(2) \\
\hline $\mathrm{P}$ & 87.2 & 29.5 & 7.3 & 9.1 & 0.3 \\
\hline $\mathrm{K}$ & 166.0 & 23.9 & 22.1 & 28.2 & 10.9 \\
\hline $\mathrm{Ca}$ & - & 99.2 & 14.0 & 90.4 & 1.0 \\
\hline $\mathrm{Mg}$ & 0.5 & 5.5 & 2.1 & 35.3 & 0.4 \\
\hline $\mathrm{S}^{\circ}$ & - & 48.4 & 24.7 & 6.1 & 3.4 \\
\hline B & 36.0 & $1,038.7$ & ${ }_{-} \mathrm{mg} \mathrm{kg}_{-}^{-}$ & 63.5 & -(1) \\
\hline $\mathrm{Cu}$ & 36.0 & 104.8 & 14.4 & 254.9 & 4.8 \\
\hline $\mathrm{Fe}$ & 500.0 & $2,127.0$ & 22.4 & $11,360.0$ & 0.6 \\
\hline $\mathrm{Mn}$ & 250.0 & 433.7 & 114.1 & $2,465.5$ & 12.6 \\
\hline $\mathrm{Zn}$ & 25.0 & $1,481.0$ & 927.7 & 282.5 & 13.6 \\
\hline Mo & 9.0 & - & - & - & - \\
\hline
\end{tabular}

(1) Scotts (2008). ${ }^{(2)}$ Not detected. 
Table 3. Root dry matter production (RDM), shoot dry matter (SDM), total dry matter (TDM), ratio of root to shoot (R/S), number of shoot units (SU), length of the longest unit of the shoot (LSU) and average length of the shoot units (ALSU) in response to organic and mineral fertilizers and their combinations

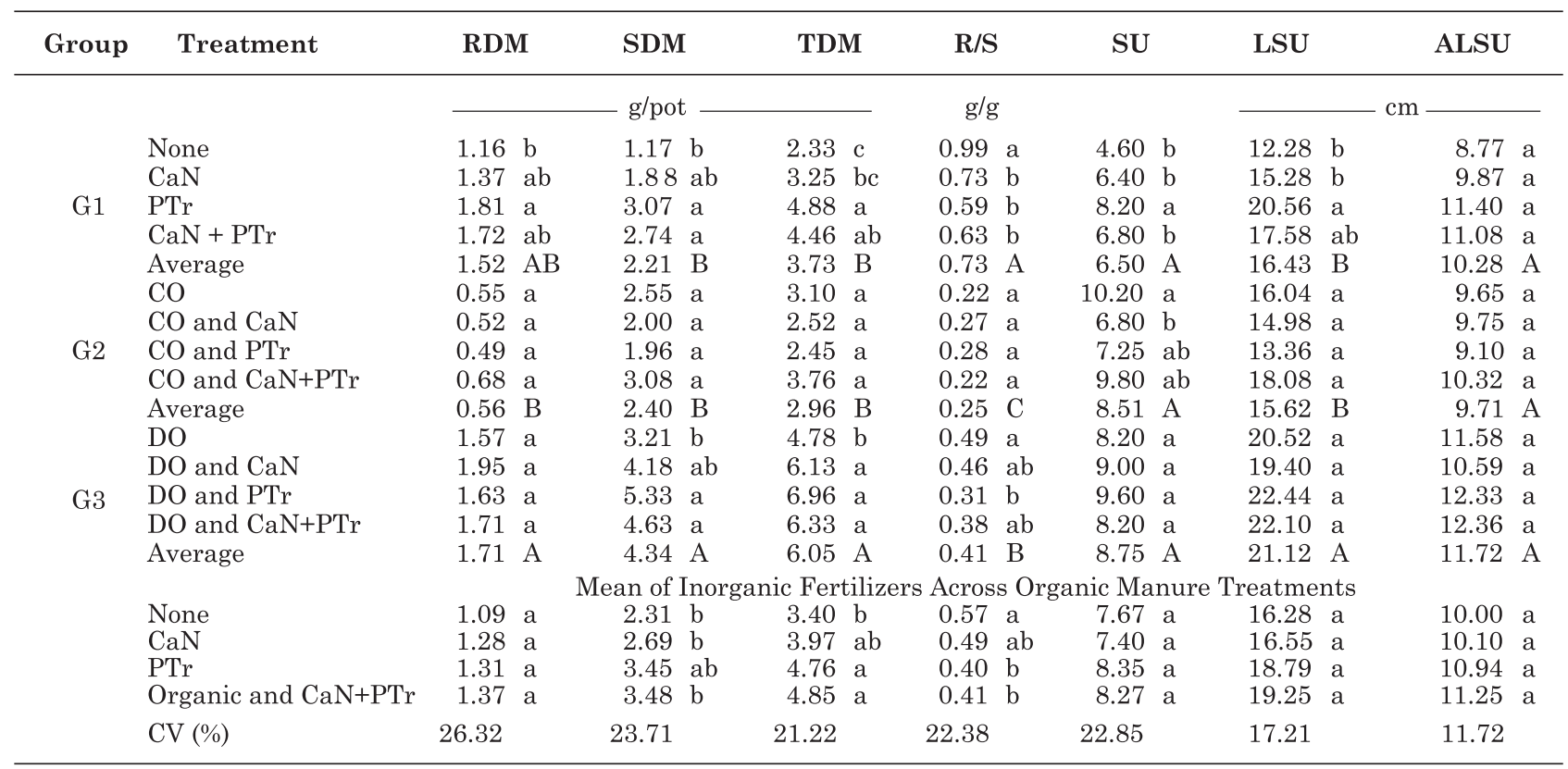

Averages followed by the same capital letter between groups and lower-case letters within a group did not differ by more than $5 \%$ by the Tukey test. CaN: Calcium nitrate, PTr: Peters ${ }^{\circledR}$ 20-20-20, CO: Commercial organic, DO: Domestic organic. G1: Treatment group without organic fertilizer, G2: Treatment group that received commercial organic fertilizer (CO), G3: Treatment group that received domestic organic fertilizer (DO). CV: Coefficient of variation.

nutrition tends to be lower than in those with nutritional restriction, similar to plants of other species (Zonta et al., 2006).

In the $\mathrm{CO}$ treatments, with an R/S of around 0.2 , plant quality and shoot dry matter production were lower than in the treatments with DO and/or Peters ${ }^{\circledR}$ fertilizer. In the latter cases, the R/S ratio was very low, which allows the conclusion that such low values are undesirable. The R/S of the plants with the best shoot growth and general aspect was between 0.31 and 0.59 (Table 3).

The results for total plant dry matter (shoot plus roots), were similar to those for shoot dry matter (Table 3). Generally speaking, in the plant group treated with domestic organic manure (DO), the trend of total dry matter production of the plant (shoot plus roots) was the same as for shoot dry matter, i.e., the average values of the total and shoot dry matter production differed statistically from the other groups (Table 3).

The number of shoot units (SU), a structure formed by the pseudobulb and leaf lamina, was greater in all fertilized treatments than in the control (Table 3). Conversely, there was no significant difference between the two organic and mineral fertilizers (Table 3). However, some differences were observed in the treatments with $\mathrm{CO}$ fertilizer: the use of $\mathrm{CO}$ along with $\mathrm{Ca}$ nitrate or Peters ${ }^{\circledR}$ resulted in a lower number of SU (Table 3).
The number of SU per pot was also greater, with significant differences between the control and the treatments with organic and/or mineral fertilizer; the best responses to organic fertilizers were obtained with DO.

The average SU length was not significantly different for the fertilizers.

\section{Nutrient concentrations}

Underlying the assessment of the nutritional status of the plants, reference values presented by Arditti (1992) and Jones Jr. et al. (1991) as critical levels for Cattleya were used, which is one of the few references for adequate nutrient level in orchids.

Nitrogen levels in the plant shoots varied significantly between the control and the organic and mineral fertilizers. A strong $\mathrm{N}$ deficiency was observed in the control, with levels around $5 \mathrm{~g} \mathrm{~kg}^{-1}$, shown by generalized chlorosis of the plant (Table 4). The treatments with CO fertilizer had higher N levels, twice as high as those in plants fertilized with the organic mixture or with mineral fertilizers (Table 4).

Phosphorus levels in plants cultivated without fertilizer or with DO and/or Ca nitrate were low, which could explain the higher dry matter production in the treatments with DO in addition to Peters $₫$ fertilizer, which is rich in $\mathrm{P}$ (Table 4). The initial $\mathrm{P}$ demand in 
Table 4. Concentrations of macro- and micronutrients in plant shoot in response to the addition of organic and mineral fertilizer and recommended sufficiency foliar concentrations

\begin{tabular}{|c|c|c|c|c|c|c|c|c|c|c|c|c|}
\hline Group & Treatment & $\mathbf{N}$ & $\mathbf{P}$ & $\mathbf{K}$ & $\mathbf{C a}$ & Mg & $\mathrm{S}$ & $\mathbf{F e}$ & $\mathrm{Zn}$ & Mn & B & $\mathbf{C u}$ \\
\hline & & & & - $\mathrm{g}$ & $\mathrm{kg}^{-1}$ & & & & & $\mathrm{mg} \mathrm{kg}^{-1}$ & & \\
\hline \multirow{7}{*}{ G1 } & None & $6.5 \mathrm{~b}$ & $0.8 \mathrm{c}$ & $19.8 \mathrm{~b}$ & $7.8 \mathrm{~cd}$ & $1.5 \mathrm{a}$ & $0.7 \mathrm{a}$ & $157 \mathrm{a}$ & $72 \mathrm{a}$ & $359 \mathrm{a}$ & $74 \mathrm{a}$ & $7.7 \mathrm{a}$ \\
\hline & $\mathrm{CaN}$ & $13.7 \mathrm{a}$ & $0.8 \mathrm{c}$ & $24.0 \mathrm{ab}$ & $15.6 \mathrm{a}$ & $1.5 \mathrm{a}$ & $1.2 \mathrm{a}$ & $117 \mathrm{a}$ & $43 \mathrm{~b}$ & $359 \mathrm{a}$ & $43 \mathrm{a}$ & $7.1 \mathrm{a}$ \\
\hline & $\mathrm{PTr}$ & $18.3 \mathrm{a}$ & $2.6 \mathrm{a}$ & $28.9 \mathrm{a}$ & $6.0 \mathrm{~d}$ & $1.5 \mathrm{a}$ & $1.3 \mathrm{a}$ & $115 \mathrm{a}$ & $24 \mathrm{~b}$ & $231 \mathrm{~b}$ & $42 \mathrm{a}$ & $5.2 \mathrm{a}$ \\
\hline & $\mathrm{CaN}$ and $\mathrm{PTr}$ & $16.1 \mathrm{a}$ & $1.9 \mathrm{~b}$ & $21.9 \mathrm{ab}$ & $11.2 \mathrm{~b}$ & $1.5 \mathrm{a}$ & $1.5 \mathrm{a}$ & $149 \mathrm{a}$ & $38 \mathrm{~b}$ & $278 \mathrm{~b}$ & 36 a & $6.9 \mathrm{a}$ \\
\hline & Average & $13.6 \mathrm{~B}$ & $1.6 \mathrm{~B}$ & $23.6 \mathrm{~A}$ & $10.1 \mathrm{~A}$ & $1.5 \mathrm{~B}$ & $1.2 \mathrm{~B}$ & $134 \mathrm{~A}$ & $44 \mathrm{~B}$ & $307 \mathrm{C}$ & $48 \mathrm{~B}$ & $7 \mathrm{~A}$ \\
\hline & $\mathrm{CO}$ & $29.5 \mathrm{a}$ & $2.4 \mathrm{a}$ & $28.1 \mathrm{ab}$ & $9.8 \mathrm{a}$ & $1.8 \mathrm{a}$ & $3.9 \mathrm{a}$ & $89 a$ & $72 \mathrm{bc}$ & $180 \mathrm{a}$ & $307 \mathrm{~b}$ & $7.7 \mathrm{ab}$ \\
\hline & $\mathrm{CO}$ and $\mathrm{CaN}$ & $30.6 \mathrm{a}$ & $2.0 \mathrm{a}$ & $22.3 \mathrm{~b}$ & $9.8 \mathrm{a}$ & $1.8 \mathrm{a}$ & $3.5 \mathrm{a}$ & $84 \mathrm{a}$ & $56 \mathrm{bc}$ & $188 \mathrm{a}$ & $271 \mathrm{~b}$ & $8.1 \mathrm{ab}$ \\
\hline \multirow[t]{5}{*}{ G2 } & $\mathrm{CO}$ and PTr & $33.8 \mathrm{a}$ & $2.4 \mathrm{a}$ & $28.8 \mathrm{ab}$ & $9.1 \mathrm{a}$ & $1.9 \mathrm{a}$ & $4.4 \mathrm{a}$ & $120 \mathrm{a}$ & $79 \mathrm{a}$ & $226 \mathrm{a}$ & $388 \mathrm{a}$ & $9.7 \mathrm{a}$ \\
\hline & $\mathrm{CO}$ and $\mathrm{CaN}+\mathrm{PTr}$ & $30.1 \mathrm{a}$ & $2.4 \mathrm{a}$ & $31.6 \mathrm{a}$ & $10.9 \mathrm{a}$ & $2.3 \mathrm{a}$ & $3.6 \mathrm{a}$ & $80 a$ & $63 \mathrm{bc}$ & $191 \mathrm{a}$ & $310 \mathrm{~b}$ & $4.8 \mathrm{~b}$ \\
\hline & Average & $31.0 \mathrm{~A}$ & $2.3 \mathrm{~A}$ & $27.7 \mathrm{~A}$ & $9.9 \mathrm{~A}$ & $1.9 \mathrm{~B}$ & $3.8 \mathrm{~B}$ & $93 \mathrm{AB}$ & $67 \mathrm{~A}$ & $196 \mathrm{~A}$ & $319 \mathrm{~A}$ & $8 \mathrm{~A}$ \\
\hline & DO & $14.1 \mathrm{a}$ & $1.0 \mathrm{~b}$ & $35.8 \mathrm{a}$ & $8.3 \mathrm{a}$ & $3.9 \mathrm{~b}$ & $1.7 \mathrm{a}$ & $74 \mathrm{a}$ & $27 \mathrm{a}$ & $98 \mathrm{a}$ & $36 \mathrm{a}$ & $5.2 \mathrm{a}$ \\
\hline & $\mathrm{DO}$ and $\mathrm{CaN}$ & $13.8 \mathrm{a}$ & $0.9 \mathrm{~b}$ & $29.6 \mathrm{~b}$ & $9.7 \mathrm{a}$ & $3.6 \mathrm{~b}$ & $1.3 \mathrm{a}$ & $66 \mathrm{a}$ & $29 \mathrm{a}$ & $185 \mathrm{a}$ & $50 \mathrm{a}$ & $5.0 \mathrm{a}$ \\
\hline \multirow[t]{10}{*}{ G3 } & $\mathrm{DO}$ and $\mathrm{PTr}$ & $16.9 \mathrm{a}$ & $1.7 \mathrm{a}$ & $28.0 \mathrm{~b}$ & $9.0 \mathrm{a}$ & $4.6 \mathrm{a}$ & $2.1 \mathrm{a}$ & $79 \mathrm{a}$ & $26 \mathrm{a}$ & $233 \mathrm{a}$ & $49 \mathrm{a}$ & $4.3 \mathrm{a}$ \\
\hline & $\mathrm{DO}$ and $\mathrm{CaN}+\mathrm{PTr}$ & $18.8 \mathrm{a}$ & $1.6 \mathrm{a}$ & $28.3 \mathrm{~b}$ & $9.9 \mathrm{a}$ & $3.8 \mathrm{~b}$ & $1.9 \mathrm{a}$ & $72 \mathrm{a}$ & $23 \mathrm{a}$ & $199 \mathrm{a}$ & $45 \mathrm{a}$ & $4.8 \mathrm{a}$ \\
\hline & Average & $15.9 \mathrm{~B}$ & $1.3 \mathrm{~B}$ & $30.4 \mathrm{~A}$ & $9.2 \mathrm{~A}$ & $4.0 \mathrm{~A}$ & $1.8 \mathrm{~B}$ & $73 \mathrm{~B}$ & $26 \mathrm{~B}$ & $204 \mathrm{~B}$ & $45 \mathrm{~B}$ & $5 \mathrm{~A}$ \\
\hline & None & $16.7 \mathrm{~b}$ & $1.4 \mathrm{~b}$ & $27.9 \mathrm{a}$ & $8.6 \mathrm{ab}$ & $2.4 \mathrm{a}$ & $2.1 \mathrm{ab}$ & $107 \mathrm{a}$ & $57 \mathrm{a}$ & $212 \mathrm{a}$ & $139 \mathrm{ab}$ & $6.9 \mathrm{a}$ \\
\hline & $\mathrm{CaN}$ & $19.4 \mathrm{ab}$ & $1.2 \mathrm{~b}$ & $25.3 \mathrm{a}$ & $11.7 \mathrm{a}$ & $2.3 \mathrm{a}$ & $2.0 \mathrm{~b}$ & 89 a & $43 \mathrm{~b}$ & $244 \mathrm{a}$ & $121 \mathrm{~b}$ & $6.8 \mathrm{a}$ \\
\hline & $\mathrm{PTr}$ & $23.0 \mathrm{a}$ & $2.2 \mathrm{a}$ & $28.6 \mathrm{a}$ & $8.0 \mathrm{~b}$ & $2.7 \mathrm{a}$ & $2.6 \mathrm{a}$ & $105 \mathrm{a}$ & $43 \mathrm{~b}$ & $230 \mathrm{a}$ & $160 \mathrm{a}$ & $6.4 \mathrm{a}$ \\
\hline & Organic and $\mathrm{CaN}+\mathrm{PTr}$ & $21.7 \mathrm{a}$ & $2.0 \mathrm{a}$ & $27.3 \mathrm{a}$ & $10.7 \mathrm{a}$ & $2.5 \mathrm{a}$ & $2.3 \mathrm{ab}$ & $100 \mathrm{a}$ & $41 \mathrm{~b}$ & $223 \mathrm{a}$ & $130 \mathrm{~b}$ & $5.5 \mathrm{a}$ \\
\hline & CV $(\%)$ & 17.00 & 19.06 & 16.31 & 15.61 & 22.49 & 22.87 & 23.54 & 17.57 & 17.65 & 19.32 & 23.54 \\
\hline & Leaf content sufficient & $16-25^{(1)}$ & $1.3-7.5$ & $21-35$ & $6-20$ & $4-7$ & $1.5-7.5$ & $25-75$ & $5-20$ & $50-200$ & $40-200$ & $25-200$ \\
\hline & & $20-35^{(2)}$ & $2-3$ & $40-60$ & $15-25$ & $4-8$ & - & $25-50$ & $10-25$ & $80-150$ & $100-200$ & $20-60$ \\
\hline
\end{tabular}

(1) Jones Jr et al. (1991), leaf results for Cattleya. ${ }^{(2)}$ Arditti (1992), leaf results for Phalaenopsis. Averages followed by the same capital letter between groups and lower-case letters within a group did not differ by more than $5 \%$ by the Tukey test. CaN: Calcium nitrate, PTr: Peters ${ }^{\circledR}$ 20-20-20, CO: Commercial organic, DO: Domestic organic. G1: Treatment group without organic fertilizer, G2: Treatment group with commercial organic fertilizer (CO), G3: Treatment group with domestic organic fertilizer (DO). CV: Coefficient of variation.

young orchid plants is probably greater than that of adult plants. In experiments in vitro, high $\mathrm{P}$ levels were found in the seedling shoots; the best responses in this case in terms of dry matter production had levels above $10 \mathrm{~g} \mathrm{~kg}^{-1}$, which would be considered extremely high in adult orchids (Novais \& Rodrigues, 2004).

Potassium levels were found to be adequate in all of the treatments, with mean values between 23.6 and 30.4 (Table 4). Jones Jr. et al (1991) determined a K leaf content between 21 and $35 \mathrm{~g} \mathrm{~kg}^{-1}$ as sufficient.

One of the greatest limitations of Peters ${ }^{\circledR}$ fertilizer has to do with the absence of $\mathrm{Ca}$ in its mixtures in general (Scott, 2008). For this reason, plants that received only this fertilizer had lower Ca shoot levels, even when compared to the control (Table 4). Calcium is a component of the cell wall, thus it is essential for the formation of new cells and the stability of cell membranes (Marschner, 1995). Consequently, symptoms of Ca deficiency occur in the plant parts that grow most intensely, which are more susceptible to fungal infections, as observed by Rodrigues et al. (2002). These authors compared the effect of a Carich fertilizer and of a Peters ${ }^{\circledR}$ fertilizer and reported frequent death of buds and young shoots, a classic symptom of Ca deficiency, which was not observed for Ca-rich fertilizer.
The Mg levels observed in the plant shoots were low (Table 4), below the range of 4 to $8 \mathrm{~g} \mathrm{~kg}^{-1}$ considered adequate (Jones et al., 1991; Arditti, 1992), except in the treatment with DO fertilizer.

The $\mathrm{S}$ values in the control and the treatments with only mineral fertilizers were below $1.5 \mathrm{~g} \mathrm{~kg}^{-1}$ (Table 4), which is considered low (Jones Jr. et al., 1991). For this nutrient no minimal level is assured either in Peters $₫$ fertilizer. The main symptom of $\mathrm{S}$ deficiency is yellowing of the young leaves, clearly observed in the control.

In the case of micronutrients, the $\mathrm{Fe}, \mathrm{Zn}$, and $\mathrm{Cu}$ levels were adequate in the plants in all treatments (Table 4). However, while experiments were being conducted, visual symptoms of probable Fe deficiency were observed in young leaves for plants treated with organic fertilizers; the shoot levels (66-120 mg kg-1) are within the range (50-200 $\mathrm{mg} \mathrm{kg}^{-1}$ ) considered adequate by Arditti (1992). Greatest Fe accumulation (157 mg kg-1) was observed in unfertilized plants (Table 4). Xaxim has high Fe levels (1,593 $\mathrm{mg} \mathrm{kg}^{-1}$ ), which can explain this result (Novais \& Rodrigues, 2004).

High Mn levels were found, above those considered adequate (40-200 mg kg-1), in unfertilized treatments, in those treated with mineral fertilizer only, and in those treated with one of the organic fertilizers along 
with Peters ${ }^{\circledR}$ (Table 4). An analysis of the micronutrient levels in orchid plants cultivated in the region of Campinas, São Paulo State, detected high Mn levels (495-800 $\left.\mathrm{mg} \mathrm{kg}^{-1}\right)$, indicating possible toxicity (Furlani \& Castro, 2001).

Boron levels were extremely elevated in CO fertilizer ( Table 4), causing toxicity symptoms. On the other hand, levels were adequate (25 to 75 ) in all other treatments (Jones et al., 1991). Furlani \& Castro (2001) suggested that the orchid genera Cattleya and Phalaenopsis tolerate high levels of this micronutrient. This trend was however not observed in this study, since B-toxicity symptoms were very evident.

\section{Nutrient accumulation}

The highest $\mathrm{K}$ accumulation resulted from utilization of DO fertilizer, given its elevated presence in the ashes that are one of its components (Table 5).

After the control, the Ca content $(9.0 \mathrm{mg} / \mathrm{plant})$ was lowest in treatmemts with Peters $®$ fertilizer (18.3 $\mathrm{mg} /$ plant), followed by CO fertilizer with Peters ${ }^{\circledR}(19.0$ $\mathrm{mg} /$ plant), as a consequence of low dry matter production in the latter. The Mg accumulation was much higher in the DO treatments. Application of only Ca nitrate and/or Peters ${ }^{\circledR}$ resulted in lower $\mathrm{S}$ accumulation than in the treatments with organic fertilizers (Table 5).
Fe accumulation in the treatments that received organic fertilizers and supplements did not differ statistically (Table 5), but was significantly higher in those with mineral fertilizer application only.

Higher $\mathrm{Zn}$ accumulation in the treatments that received $\mathrm{CO}$ fertilizer were the result of higher concentrations of this nutrient in the fertilizer. In the DO treatments, the high $\mathrm{Zn}$ accumulation was due to the greater dry matter production (Table 5).

Manganese was accumulated most in the DO treatments.

Due to the high B contents in CO-treated plants, the contents of this micronutrient reached values of around $1 \mathrm{mg} /$ plant, while in the other treatments this value did not exceed $0.26 \mathrm{mg} / \mathrm{plant}$. Copper accumulation in the shoot varied in the treatments from 0.013 to $0.024 \mathrm{mg} / \mathrm{plant}$; however, these differences were not significant.

\section{CONCLUSIONS}

1. Boron levels were extremely high in commercial organic fertilizer $(\mathrm{CO})$, which resulted in a strong toxicity effect on CO-treated plants.

Table 5. Accumulation of macro- and micronutrients in plant shoot in response to the addition of organic or mineral fertilizers

\begin{tabular}{|c|c|c|c|c|c|c|c|c|c|c|c|c|}
\hline Group & Treatment & $\mathbf{N}$ & $\mathbf{P}$ & $\mathbf{K}$ & $\mathbf{C a}$ & $\mathrm{Mg}$ & $\mathbf{S}$ & $\mathbf{F e}$ & $\mathrm{Zn}$ & Mn & B & $\mathbf{C u}$ \\
\hline & & & & & & & & & & & & \\
\hline \multirow{5}{*}{ G1 } & None & $7.6 \mathrm{c}$ & $1.0 \mathrm{c}$ & $23.1 \mathrm{~b}$ & $9.0 \mathrm{~b}$ & $1.7 \mathrm{a}$ & $0.9 \mathrm{a}$ & $0.033 \mathrm{a}$ & $0.083 \mathrm{a}$ & $0.419 \mathrm{a}$ & $0.089 a$ & $0.015 \mathrm{a}$ \\
\hline & $\mathrm{CaN}$ & $25.7 \mathrm{bc}$ & $1.6 \mathrm{c}$ & $44.8 \mathrm{ab}$ & $29.2 \mathrm{a}$ & $2.8 \mathrm{a}$ & $2.3 \mathrm{a}$ & $0.014 \mathrm{~b}$ & $0.081 \mathrm{a}$ & $0.633 \mathrm{a}$ & $0.080 \mathrm{a}$ & $0.013 a$ \\
\hline & $\mathrm{PTr}$ & $56.2 \mathrm{a}$ & $8.1 \mathrm{a}$ & $89.0 \mathrm{a}$ & $18.3 \mathrm{ab}$ & $4.6 \mathrm{a}$ & $4.0 \mathrm{a}$ & $0.013 \mathrm{~b}$ & $0.073 \mathrm{a}$ & $0.710 \mathrm{a}$ & $0.129 a$ & $0.021 \mathrm{a}$ \\
\hline & $\mathrm{CaN}$ & $44.4 \mathrm{~b}$ & $5.2 \mathrm{~b}$ & $61.6 \mathrm{ab}$ & $30.8 \mathrm{a}$ & $4.2 \mathrm{a}$ & $4.1 \mathrm{a}$ & $0.023 \mathrm{ab}$ & $0.095 \mathrm{a}$ & $0.761 \mathrm{a}$ & $0.098 \mathrm{a}$ & $0.019 a$ \\
\hline & Average & $33.5 \mathrm{~A}$ & $4.0 \mathrm{~A}$ & $54.6 \mathrm{~B}$ & $21.8 B$ & $3.3 \mathrm{~B}$ & $2.8 \mathrm{~B}$ & $0.021 \mathrm{~A}$ & $0.083 \mathrm{~A}$ & $0.631 \mathrm{AB}$ & $0.099 B$ & $0.017 \mathrm{~A}$ \\
\hline \multirow{5}{*}{ G2 } & $\mathrm{CO}$ & $75.3 \mathrm{ab}$ & $6.0 \mathrm{a}$ & $74.4 \mathrm{ab}$ & $24.8 \mathrm{ab}$ & $4.6 \mathrm{a}$ & $10.1 \mathrm{a}$ & $0.006 \mathrm{a}$ & $0.182 \mathrm{a}$ & $0.464 \mathrm{a}$ & $0.802 \mathrm{ab}$ & $0.015 \mathrm{a}$ \\
\hline & $\mathrm{CO}$ and $\mathrm{CaN}$ & $60.6 \mathrm{ab}$ & $4.0 \mathrm{~b}$ & $44.6 \mathrm{~b}$ & $19.8 \mathrm{ab}$ & $3.5 \mathrm{a}$ & $6.8 \mathrm{a}$ & $0.008 \mathrm{a}$ & $0.123 \mathrm{a}$ & $0.349 \mathrm{a}$ & $0.592 b$ & $0.017 \mathrm{a}$ \\
\hline & $\mathrm{CO}$ and $\mathrm{PTr}$ & $65.0 \mathrm{ab}$ & $5.2 \mathrm{ab}$ & $53.1 b$ & $19.0 \mathrm{~b}$ & $3.6 \mathrm{a}$ & $8.4 \mathrm{a}$ & $0.004 \mathrm{a}$ & $0.150 \mathrm{a}$ & $0.430 \mathrm{a}$ & $0.731 b$ & $0.019 \mathrm{a}$ \\
\hline & $\mathrm{CO}$ and $\mathrm{CaN}+\mathrm{PTr}$ & $92.9 \mathrm{a}$ & $7.3 \mathrm{a}$ & $97.1 \mathrm{a}$ & $33.6 \mathrm{a}$ & $7.0 \mathrm{a}$ & $11.0 \mathrm{a}$ & $0.007 \mathrm{a}$ & $0.197 \mathrm{a}$ & $0.586 \mathrm{a}$ & $0.974 \mathrm{a}$ & $0.015 \mathrm{a}$ \\
\hline & Average & $73.4 \mathrm{~A}$ & $5.6 \mathrm{~A}$ & 67.3B & $24.3 B$ & $4.7 \mathrm{~B}$ & $9.1 \mathrm{~A}$ & $0.006 \mathrm{~B}$ & $0.163 A$ & $0.457 \mathrm{~B}$ & $0.774 \mathrm{~A}$ & $0.017 \mathrm{~A}$ \\
\hline \multirow{10}{*}{ G3 } & DO & $44.2 \mathrm{~b}$ & $3.1 \mathrm{~b}$ & $113.8 \mathrm{a}$ & $27.3 \mathrm{~b}$ & $12.2 \mathrm{~b}$ & $5.1 \mathrm{c}$ & $0.008 \mathrm{a}$ & & $0.651 b$ & $0.115 \mathrm{a}$ & $0.018 \mathrm{a}$ \\
\hline & $\mathrm{DO}$ and $\mathrm{CaN}$ & $57.9 \mathrm{~b}$ & $3.6 \mathrm{~b}$ & $125.4 \mathrm{a}$ & $41.7 \mathrm{ab}$ & $15.2 \mathrm{~b}$ & $5.7 \mathrm{bc}$ & $0.016 \mathrm{a}$ & $0.126 \mathrm{a}$ & $0.798 b$ & $0.219 \mathrm{a}$ & $0.023 \mathrm{a}$ \\
\hline & $\mathrm{DO}$ and $\mathrm{PTr}$ & $89.5 \mathrm{a}$ & $8.9 \mathrm{a}$ & $149.8 \mathrm{a}$ & $48.2 \mathrm{a}$ & $24.7 \mathrm{a}$ & $11.3 \mathrm{a}$ & $0.006 \mathrm{a}$ & $0.138 \mathrm{a}$ & $1.242 \mathrm{a}$ & $0.259 \mathrm{a}$ & $0.024 \mathrm{a}$ \\
\hline & $\mathrm{DO}$ and $\mathrm{CaN}+\mathrm{PTr}$ & $85.2 \mathrm{ab}$ & $7.1 \mathrm{ab}$ & $131.3 \mathrm{a}$ & $44.9 \mathrm{a}$ & $17.7 \mathrm{~b}$ & $10.2 \mathrm{ab}$ & $0.007 \mathrm{a}$ & $0.114 a$ & $0.910 \mathrm{~b}$ & $0.216 \mathrm{a}$ & $0.022 \mathrm{a}$ \\
\hline & Average & $69.2 \mathrm{~A}$ & $5.7 \mathrm{~A}$ & $130.1 \mathrm{~A}$ & $40.5 \mathrm{~A}$ & $17.5 \mathrm{~A}$ & $8.1 \mathrm{~A}$ & $0.009 \mathrm{AB}$ & $0.116 \mathrm{~A}$ & $0.900 \mathrm{~A}$ & $0.202 \mathrm{~B}$ & $0.022 \mathrm{~A}$ \\
\hline & None & $42,36 \mathrm{~b}$ & $3,4 \mathrm{~b}$ & $70,4 \mathrm{~b}$ & $20,4 \mathrm{~b}$ & $6,2 \mathrm{~b}$ & $5,4 \mathrm{ab}$ & $0,016 \mathrm{a}$ & $0,117 \mathrm{a}$ & $0,511 b$ & $0,335 \mathrm{a}$ & $0,016 \mathrm{a}$ \\
\hline & $\mathrm{CaN}$ & $48,07 \mathrm{~b}$ & $3,1 b$ & $71,6 \mathrm{ab}$ & $30,2 \mathrm{a}$ & $7,2 \mathrm{~b}$ & $4,9 \mathrm{~b}$ & $0,013 \mathrm{a}$ & $0,110 \mathrm{a}$ & $0,593 \mathrm{ab}$ & $0,297 \mathrm{a}$ & $0,016 \mathrm{a}$ \\
\hline & $\mathrm{PTr}$ & $69,20 \mathrm{a}$ & $7,4 \mathrm{a}$ & $97,3 \mathrm{a}$ & $28,5 \mathrm{ab}$ & $11,0 \mathrm{a}$ & $7,9 \mathrm{ab}$ & $0,008 \mathrm{a}$ & $0,120 \mathrm{a}$ & $0,794 \mathrm{a}$ & $0,373 a$ & $0,021 \mathrm{a}$ \\
\hline & Organic and $\mathrm{CaN}+\mathrm{PTr}$ & $74,20 \mathrm{a}$ & $6,5 \mathrm{a}$ & $96,7 \mathrm{ab}$ & $36,4 \mathrm{a}$ & $9,6 \mathrm{ab}$ & $8,4 \mathrm{a}$ & $0,012 \mathrm{a}$ & $0,135 \mathrm{a}$ & $0,752 \mathrm{a}$ & $0,429 a$ & $0,019 a$ \\
\hline & CV $(\%)$ & 30.40 & 33.08 & 28.77 & 29.73 & 41.03 & 43.17 & 45.27 & 31.86 & 29.30 & 37.97 & 23.54 \\
\hline
\end{tabular}

Averages followed by the same capital letter between groups and lower-case letters within a group did not differ by more than $5 \%$ by the Tukey test. CaN: Calcium nitrate, PTr: Peters ${ }^{\circledR}$ 20-20-20, CO: Commercial organic, DO: Domestic organic. G1: Treatment group without organic fertilizer, G2: Treatment group with commercial organic fertilizer (CO), G3: Treatment group with domestic organic fertilizer (DO). CV: Coefficient of variation. 
2. Mineral fertilizers such as Peters ${ }^{\circledR}$ should be supplemented with a source of $\mathrm{Ca}$ and $\mathrm{S}$ since the deficiency of these macronutrients is growth-limiting.

3. Domestic organic fertilizer (DO), utilized along with mineral fertilizer, induced great increases in plant dry matter production.

4. The result of the use of calcium nitrate as a $\mathrm{Ca}$ source to complement Peters ${ }^{\circledR}$ was deficient due to the lack of $\mathrm{S}$ in Peters ${ }^{\circledR}$.

\section{LITERATURE CITED}

AMBERGER-OCHSENBAUER, S. Nutrition and postproduction performance of Phalaenopsis pot plants. Acta Hort., 450:105-112, 1997.

ARDITTI, J. Fundamentals of orchid biology. New York, John Wiley \& Sons, 1992. 691p.

CARLUCCI, M.V.; HAAG, H.P. \& BELLOTE, A.F.J. Nutrição mineral de plantas ornamentais. IX. Composição química e extração de nutrientes por cinco espécies de Orchidaceae In: HAAG, H.P.; MINAMI, K. \& LIMA, A.M.L.P., eds. Nutrição mineral de algumas espécies ornamentais. Campinas, Fundação Cargill, 1989. p.27-34.

EMPRESA BRASILEIRA DE PESQUISA AGROPECUÁRIA EMBRAPA. Manual de análises químicas de solos, plantas e fertilizantes. Brasília, Embrapa Comunicação para Transferência de Tecnologia, 1999. 370p.

ERICKSON, L.C. Respiration and photosynthesis in Cattleya roots. Am. Orch. Soc. Bull., 26:401-402, 1957.

FURLANI, A.M.C. \& CASTRO, C.E.F. Plantas ornamentais e flores. In: FERREIRA, M.E.; CRUZ, M.C.P.; RAIJ, B.van. \& ABREU, C.A., eds. Micronutrientes e elementos tóxicos na agricultura. Jaboticabal, CNPq/FAPESP/POTAFÓS, 2001. p.533-552.

JONES Jr, J.B.; WOLF, B. \& MILLS, H.A. Plant analysis handbook. Athens, Micro-Macro Publishing, 1991. 213p.

MARSCHNER, H. Mineral nutrition of higher plants. London, Academic Press, 1995. 888p.
MEURER, E.J. Fatores que influenciam o crescimento e o desenvolvimento de plantas In: NOVAIS, R.F.; ALVAREZ V., V.H., BARROS, N.F.; FONTES, R.L.F.; CANTARUTTI, R.B. \& NEVES, J.C.L., eds. Fertilidade do solo. Viçosa, MG, Sociedade Brasileira de Ciência do Solo, 2007. p.6590 .

NABLE, R.O.; BAÑUELOS, G.S. \& PAULL, J.G. Boron toxicity. Plant Soil, 198:181-198, 1997.

NOVAIS, R.F. \& RODRIGUES, D.T. Nutrição e fertilização de orquídeas. In: CONGRESSO BRASILEIRO DE BOTÂNICA, 2004, Viçosa, MG. Simpósios Palestras e Mesas Redondas. Viçosa, MG, Sociedade Botânica do Brasil, 2004. CD-ROM

RODRIGUES, D.T.; ALVAREZ V., V.H. \& NOVAIS, R.F. Crescimento de um híbrido de orquídea em resposta a fertilizantes, doses e modo de aplicação. In: FERTIBIO, 2002, Rio de Janeiro. Anais... Rio de Janeiro, 2002. CDROM

RODRIGUES, D.T. Nutrição e fertilização de orquídeas in vitro e em vasos. Viçosa, MG, Universidade Federal de Viçosa, 2005. 90p. (Tese de Mestrado)

SCOTTS Peters Professional. Available at: <http:// www.scottsinternational.com/en/range/10 $>$. Accessed on Aug 10, 2008.

WANG, Y.T. \& GREGG, L.L. Medium and fertilizer affect the performance of Phalaenopsis orchids during two flowering cycles. Hortic. Sci., 29:269-271, 1994.

WANG, Y.T. Effects of six fertilizers on vegetative growth and flowering of Phalaenopsis orchids. Sci. Hortic., 65:191-197, 1996.

WANG, Y.T. Impact of a high phosphorus fertilizer and timing of termination of fertilization on flowering of a hybrid of moth orchid. Hortic. Sci., 35:60-62, 2000.

ZONTA, E.; BRASIL, F.C.; GOI, S.R. \& ROSA, M.M.T. O sistema radicular e suas interações com o ambiente edáfico. In: FERNANDES, M. S., ed. Nutrição mineral de plantas. Viçosa, MG, Sociedade Brasileira da Ciência do Solo, 2006. p.8-28. 